\title{
The Shift of Politeness Systems in Javanese Society: A Case Study in Urban Communities in the Arek Cultural Area
}

\author{
Edy Jauhari ${ }^{1}$, Dwi Purnanto ${ }^{2}$ \\ \{edy-j@fib.unair.ac.id\} \\ Doctor of Law, Universitas Jayabaya, Jakarta, Indonesia
}

\begin{abstract}
This paper examines the shift of politeness system of Javanese society in the Arek cultural area, especially in urban community. The shift is seen based on differences in generations, namely the younger generation (adolescents) with age around 15-20 years (second generation) and the generation of their parents aged 45 years and over (the first generation). The data in this paper were collected through in-depth interviews with informants and analyzed using the Scollon and Scollon (2001) theory. The results of the data analysis show that the politeness system of the Javanese Arek cultural community is showing a shift process, from a hierarchical politeness system to symmetrical politeness system. The shift was triggered by the passive mastery of the second-generation karma level. When communicating with the first generation, the second generation tends not to use krama level, but Indonesian. This language is used to realize independent strategies so that it is as if Indonesian is a form of krama from Javanese at the ngoko level.
\end{abstract}

Keywords: the shift, politeness systems, Javanese ethnicity, Arek culture

\section{Introduction}

Politeness has a very important function in human life. Politeness serves to build social cooperation and harmony. Politeness is universal, needed, and owned by all groups of people around the world. However, this does not mean that all groups of society have the same way of expressing politeness. The fact shows that each community group often expresses politeness in different ways. These differences seem very reasonable because each community or ethnic group, in general, has different traditions, customs, and value systems. These differences can cause their way of expressing politeness to be different. Even within the same cultural group, expressions of politeness can be somewhat different due to the sub-culture they have.

The politeness system of a community group is not static, but dynamic, it can experience shifts, even changes, along with the development and changes in the community group concerned. One of the ways of this shift is that it can be seen across generations, by comparing one generation group with another generation group that is above or below it in the same period of time. Why it should be seen from across generations because each generation can represent a different era with values and norms that can be different too. Generations of parents, for example, may display values or norms that are somewhat different from those of their children or their grandchildren. The difference in values and norms includes differences in how to judge something about what is considered good or bad, polite or impolite. 
Therefore, based on this comparison, it will be known whether these generational differences show different judgments of politeness, in the sense that what is said to be polite by one generation group is considered impolite by another generation group. If the answer is yes, it means there is a shift in politeness.

Based on my observations, the shift of the politeness system seems to be taking place in the Javanese ethnic community, especially in the cultural area of Arek, East Java. Therefore, this paper specifically examines the shift in the region. As stated above, the shift is seen based on differences in generations, namely the younger generation and the older generation. The younger generation (second generation) is determined by the age of 15-20 years, while the older genera. In this paper, it is assumed that at least 45 years of age can have children with a maximum age of 20 years.

Therefore, 45 years old is considered the lowest age for the first generation, while 20 years old is considered the highest for the second generation (first generation) is the generation of their parents or grandparents aged 45 years and over. Meanwhile, generations 21-44 years of age are categorized as the intermediate generation, while generations under 15 years of age are categorized as children. In this paper, the intermediate generation and generation of children are not discussed because they do not show any shifting phenomenon. Since this shift is more pronounced in urban than in rural areas, this study focuses on urban areas.

Studies on this shift in politeness can actually use one of the several existing politeness theory models, namely the social norm, the conversational maxim, the face-saving, and the conversational contract model. Social norms and conversational maxims models, for example, can be seen in (Leech 1983)[1] and (Leech 2014)[2], the face-saving model can be seen in (Brown and Levinson 1978) [3] and (Scollon and Scollon 2001)[4]. The conversation contract model can be seen in (Fraser 1990) [5] dan (Watts 2003) [6]. However, because this paper talks about the politeness system, the politeness theory that is considered appropriate is the theory of (Scollon and Scollon 2001). They argue that based primarily on whether there are differences in power $(+\mathrm{P})$ or $(-\mathrm{P})$ and the distance between participants $(+\mathrm{D})$ or $(-\mathrm{D})$, we can distinguish three politeness systems: the deference politeness system, the solidarity politeness system, and the hierarchical politeness system.

So far there have been several researchers who have conducted research on Javanese language and politeness in Javanese society. Among them are (Wajdi 2013)[7], (Sukarno 2010)[8], (Wijayanto 2013)[9] (Indrayanto and Yuliastuti 2015)[10], (Mardikantoro 2012)[11], (Wajdi 2011)[12], (Wajdi 2010)[13]. P Their research is certainly different from this research. This research specifically examines the shift in the politeness system, especially in the Javanese Arek cultural area that has never been discussed by previous researchers

\section{Research Methods}

This study uses a qualitative approach. Data is not intended to prove the truth of the hypothesis but is used as a basis for making conclusions or theories. Data analysis was performed inductively. The data in this paper were collected through in-depth interviews with informants. Because this study involved two different generations, namely the younger generation (with an age range of 15-20 years) and the generation of their parents (those aged 45 years and over), informants naturally also came from these two generations. Henceforth, the generation with 15-20 years of age is called the second generation (G-2), while the generation with the age of 45 years and over is called the first generation $(\mathrm{G}-1)$. 


\section{Results and Discussion}

\subsection{The Context of Politeness System Shift}

The shift of politeness systems in this paper is seen from a number of contexts. These contexts are determined based on two sociological variables, namely power $(\mathrm{P})$ and social distance (D). $\mathrm{P}$ is further divided into three sub-variables, namely $(+\mathrm{P}),(-\mathrm{P})$, and $(=\mathrm{P}) .(+\mathrm{P})$ means the second participant $(\mathrm{P} 2)$ has higher power than the first participant $(\mathrm{P} 1)$. $(-\mathrm{P})$ means that $\mathrm{P} 2$ has lower power than $\mathrm{P} 1 .(=\mathrm{P})$ means that $\mathrm{P} 2$ and $\mathrm{P} 1$ have more or less the same power. Power in Javanese society can take the form of differences in social status or differences in age. P2 with higher social status or older age can have higher power than P1, and vice versa.

Furthermore, D can be divided into two sub-variables, namely (+D) and (-D). (+D) means that relations $\mathrm{P} 1$ and $\mathrm{P} 2$ are not familiar, while (-D) means that relations $\mathrm{P} 1$ and $\mathrm{P} 2$ are familiar. If the two sociological variables and their sub-variables above interact with one another, then it can form a number of context situations, namely (=P-D), (=P+D), (-P-D), (-P+D), (+P-D), and $(+\mathrm{P}+\mathrm{D})$ The shift of politeness system in this paper is seen based on the above contexts.

\subsection{The politeness System of G-1}

In daily life, G-1 generally uses two different languages, namely Indonesian and Javanese. Indonesian in general tends to be used in contexts that are national or official in nature. On the other hand, the Javanese language tends to be used in a regional context. It is true that the Javanese language they use is somewhat different from the Javanese language in the Matarama Javanese cultural area. The Javanese language of the Arek culture (especially in the city of Surabaya) is often referred to as the Suroboyoan language or the Javanese language of the Surabaya dialect. However, this Suroboyoan language has the same principles as Javanese in general which can be broadly distinguished on the level of ngoko and krama. The following shows an example of dialogue (1) which shows how the use of Javanese ngoko and kromo in the Arek cultural community.

(1) P1: Monggo dahar riyen! 'Please eat first' (ngoko level)

P2: Kulo pun dahar, nembe mawon iwak sambel kalih krupuk. 'I have eaten, just now, side dishes of chili sauce and crackers' (karma level)

Dialogue (1) takes place in a thanksgiving event in context (-P-D). P1 uses the ngoko level to $\mathrm{P} 2$, while $\mathrm{P} 2$ responds to $\mathrm{P} 1$ with krama level. For the Javanese of Mataram, P2's speech may be considered a bit strange. First, the word dhahar is used for him/herself which according to Mataram culture is impolite. Second, sambel and krupuk are said to be iwak. According to the Mataram culture, sambel and krupuk cannot be said to be iwak, but according to the Arek culture, they are considered normal.

What needs to be understood is that the use of the ngoko and krama levels tends to be complementary. This means that the level of ngoko is only suitable for use in certain contexts that cannot be simply replaced by the level of manners. On the other hand, the level of manners is also only suitable for use in certain contexts that cannot be simply replaced by the level of ngoko. The data show that the level of ngoko among G-1s is only suitable for use in close relationships. Conversely, the level of krama tends to be suitable only in unfamiliar relationships. This is in line with the results of previous research conducted by (Poedjosoedarmo, et.al. 3013) [14] and Ngadiman, 1974 [15].

If associated with the theory of Scollon and Scollon (2001), the ngoko level appears to be used by G-1 to realize the involvement strategy, while the karma level is used to realize the independence strategy. As noted by Scollon and Scollon, the involvement strategy is used to show a close relationship, while the independence strategy is used to show social distance. 
Like the use of ngoko and krama levels, the use of involvement and independence strategy should not be arbitrary. This is very much determined by how the context is. In certain contexts, the involvement strategy may be more appropriate, but in other contexts, the independence strategy is more appropriate. The use of these two types of strategies will in turn determine the politeness system, whether in a certain context the politeness system applied is the deference politeness system, the solidarity politeness system, or the hierarchical politeness system. Therefore, to be able to understand the politeness system, it must first be understood the context of using the two types of strategies. In other words, the politeness system cannot be identified before the context of using the two types of strategies is properly understood. Therefore, the following paragraphs describe the context of using these two types of strategies.

The data show that in context (=P-D), P1 and P2 in G-1 tend to mutually use the involvement strategy. The use of this strategy seems not only to be influenced by one factor, for example (D) or $(=P)$ alone but is influenced by both factors simultaneously. This can be proven by the fact that if one of the two factors is changed, for example $(=\mathrm{P})$ is changed to $(+\mathrm{P})$ or $(-$ D) is changed to (+D), the strategy used can change, from involvement to independence. Thus, it can be concluded that in the context (=P-D) G-1 tends to use the solidarity politeness system.

On the other hand, in the context of $(=\mathrm{P}+\mathrm{D}), \mathrm{P} 1$ and $\mathrm{P} 2$ in $\mathrm{G}-1$ tend to use the independence strategy. The use of this strategy is certainly not only influenced by $(+\mathrm{D})$ or $(=\mathrm{P})$ but is influenced by both simultaneously. It is evident that if one of the two factors is changed, for example from $(=\mathrm{P})$ to $(+\mathrm{P})$ or from $(+\mathrm{D})$ to $(-\mathrm{D})$, the use of the strategy can change, from independence to involvement. Thus, it can be concluded that in the context of $(=\mathrm{P}+\mathrm{D}) \mathrm{G}-1$ tends to use a deference politeness system.

Furthermore, in the context of (+P-D) and (-P-D), G-1 seems to tend to use a hierarchical politeness system. $\mathrm{P} 1$ in context $(+\mathrm{P}-\mathrm{D})$ tends to use the independence strategy, whereas $\mathrm{P} 2$ uses the involvement strategy. In contrast, P1 in the context of (-P-D) tends to use the involvement strategy, whereas P2 uses the independence strategy. It seems that the use of strategy in these two contexts is strongly influenced by factors $( \pm P)$. In G-1, there is a norm that participants with lower power must use the independence strategy, while those with higher levels may use the involvement strategy. Violation of this norm can pose a threat to the face. Meanwhile, (-D) in both contexts did not really determine the choice of strategy. Therefore, why in the context of (+P-D) P1 uses the independence strategy, whereas P2 uses the involvement strategy. In contrast, in context (-P-D), P1 uses the involvement strategy, whereas P2 uses the independence strategy. Thus, it can be concluded that in the context of (+P-D) and (-P-D) G-1 tends to apply a hierarchical politeness system in their communications.

In the context of $(+\mathrm{P}+\mathrm{D})$ and $(-\mathrm{P}+\mathrm{D}), \mathrm{G}-1$ also tends to apply a hierarchical politeness system. In context $(+\mathrm{P}+\mathrm{D}), \mathrm{P} 1$ must use the independence strategy, whereas $\mathrm{P} 2$ may use the involvement strategy, or it is not mandatory to use the independence strategy. On the other hand, in the context (-P+D), P1 may use the involvement strategy, or it is not mandatory to use the independence strategy, whereas $\mathrm{P} 2$ should use the independence strategy instead. It seems that the use of strategy in both contexts is strongly influenced by the $(+\mathrm{P})$ factor. Participants with lower power should use the independence strategy, while those with higher levels may use the involvement strategy. The factor $(+\mathrm{D})$ does not appear to have much influence on the choice of strategy. That is why in the context of $(+\mathrm{P}+\mathrm{D}) \mathrm{P} 1$ is obliged to use the independence strategy, whereas in the context of (-P+D) P2 is obliged to use the independence strategy. On the other hand, in the context of $(+\mathrm{P}+\mathrm{D}), \mathrm{P} 2$ is not obliged to use the independence strategy, whereas in the context of $(-\mathrm{P}+\mathrm{D}) \mathrm{P} 2$ is instead obliged to use the independence strategy. Thus, it can be concluded that in the context of $(+\mathrm{P}+\mathrm{D})$ and $(-\mathrm{P}+\mathrm{D}) \mathrm{G}-1$ tends to apply a hierarchical politeness system in their communications. 


\subsection{The Politeness System of G-2}

Like the G-1, in their daily life, the G-2 generally also uses two types of language, namely Indonesian and Javanese. What is interesting is that the Javanese they tend to use is the ngoko level. They tend not to use krama levels because they generally only master this level passively. This is very similar to the ethnic Chinese language in the Arek cultural area (Jauhari and Purnanto 2019) [16]. The question is how do the G-2 manifest the strategy of involvement and independence in their communication?

The data show that to show the strategy of involvement and independence, the G-2 tends to use the same level of Javanese, namely ngoko. The involvement and independence strategy are indicated only by the difference in the use of the second persona pronoun. This can be observed in the following dialog (2).

(2) P1: Koen wis tanda tangah Sum? 'Have you signed, Sum?' (ngoko level)

P2: Durung. Sampeyan wis tah Cak Edy? 'Not yet. Are you Cak Edy?' (ngoko level)

If observed, both P1 and P2 in dialogue (2) use the same level of Javanese language, namely ngoko. However, if we look at the use of personal pronouns, P1 and P2 use different personal pronouns. P1 uses koen to P2, while P2 uses sampeyan to P1. This difference does not happen by chance but has to do with politeness strategies. In the Arek cultural community, the pronoun sampeyan shows more deference or social distance (-D), while koen indicates intimacy (-D).

Thus, it can be concluded that at G-2, independence and involvement strategies were manifested through Javanese with the same level, namely ngoko, but with the use of a different second persona pronoun, sampeyan for independence and koen for involvement. The question is what the context in using the two strategies in the G-2 is and how the application of the politeness system is. The data analysis shows that the context for the use of the involvement strategy and independence on G-2 shows similarities with G-1. This similarity occurs in all types of contexts, namely (= P-D), (=P+D), (-P-D), (-P+D), (+P-D), and (+P+D).

\subsection{The Shift of the Politeness Value}

The shift in the value of politeness can be clearly observed when there is cross-generational communication between G-1 and G-2. The data show that when talking to G-1, G-2 tend not to use krama level, but Indonesian. This language is used to indicate deference (as a form of independence strategy) to the G-1. This can be observed in the following dialog (3).

(3) G-1: Iki sepeda motore sopo diparkir nduk kene iki. 'Whose motorbike is parked here?' (ngoko level)

G-2: Nggak tahu ya Pak. Mungkin punya-nya petugas PLN. 'I don't know sir. Maybe it belongs to the PLN officer.' (Indonesian language)

Dialogue (3) occurs across generations. In the dialogue, G-1 used the ngoko level for the G2. This is natural because the G-1 is much older than the G-2. What's interesting is that the G2 responded to the G-1 not at the krama level, but in Indonesian. The use of Indonesian by the G2 has the same function as the krama level in the G-1, which is to show the independence strategy. Its characteristic is that the use of Indonesian cannot be replaced by ngoko level, but can only be replaced by krama level. Why didn't the G-2 use the krama level? The data shows that the G-2 generally only mastered the krama level passively. They tend not to be confident about using it actively. Therefore, instead, Indonesian is used with the same function as the level of karma.

In section 2.3 it is explained that when the G-2 communicates with the same generation (fellow G-2s), the independent strategy and involvement are manifested in Javanese with the 
same level, namely ngoko, but with differences in the use of the second persona pronoun. However, when the G-2 communicated with the G-1, the independence strategy was implemented in a different language, namely Indonesian. It seems that G-2 realized that they might not dare to use independence strategy with ngoko level when communicating with G-1. The G-1 definitely considered this to be impolite. This means that there has been a shift in the value of politeness at G-2. What the G-2 said was polite, in fact, the G-1 considered impolite.

It seems that the use of Indonesian as a form of independence strategy will only be temporary as long as the G-1 (their parents' generation and their grandparents) are still around. Over time, when the G-2 was the same age as the G-1, it seems that the use of Indonesian as a form of independence strategy is no longer needed. What applies is the independence strategy which is manifested at the ngoko level with a difference in the second person pronoun. In fact, according to G-1, the level of ngoko, regardless of the difference in the second person pronoun, is not a form of independence strategy, but involvement. That is why G-1 considers it disrespectful to G-2 when using the difference in second-person pronouns as a form of independence strategy.

Based on the above description, it seems that the politeness system applied by the G-2 is undergoing a shift process that leads to symmetrical politeness system. This means that the hierarchical politeness system currently implemented by the G-1 in certain contexts such as (+ $\mathrm{P}+\mathrm{D}),(+\mathrm{P}-\mathrm{D}),(-\mathrm{P}+\mathrm{D}),(-\mathrm{P}-\mathrm{D})$ will change to become symmetrical politeness system. In the context of $(+\mathrm{P}+\mathrm{D})$ and $(+\mathrm{P}+\mathrm{D})$ the change becomes a deference politeness system, while in the context of (+P-D) and (+P-D) the change becomes solidarity politeness. This shift seems to have been triggered by the G-2's use of the Indonesian language as a means of realizing the independence strategy in which the G-1 manifested at a krama level. In addition, the ngoko level, regardless of the use of a different second-person pronoun, for realizing the independence strategy is actually the ngoko level as well. Based on this, the G-2 politeness system is showing a process of shift or change, from a hierarchical politeness system to symmetrical politeness system.

\section{Conclusion}

Basically, the Javanese ethnic community in the Arek cultural area applies three politeness systems in their daily communication. In the context (= P-D) they apply the solidarity politeness system. In the context $(=\mathrm{P}+\mathrm{D})$ they apply a deference politeness system. In the context of $(+\mathrm{P}+\mathrm{D}),(+\mathrm{P}-\mathrm{D}),(-\mathrm{P}+\mathrm{D}),(-\mathrm{P}-\mathrm{D})$ they tend to apply a hierarchical politeness system. However, today the politeness system seems to be showing a shifting process, especially in the G- 2 . The shift is mainly seen from the communication that occurs in the context of $(+P+D),(+P-D),(-P$ $+\mathrm{D}),(-\mathrm{P}-\mathrm{D})$.

In this context, the G-1 tends to apply a hierarchical politeness system, but the G2 shows a shifting process. In the context of $(+\mathrm{P}+\mathrm{D}$ and $(-\mathrm{P}+\mathrm{D})$ the shift occurred from a hierarchical politeness system to a deference politeness system with Indonesian as a form of independence strategy, whereas in the context (+P-D) and (-P-D) the shift occurred from a hierarchical politeness system to solidarity politeness system with the ngoko level as a form of involvement strategy. The shift seems to be triggered by passive mastery of the G-2 krama level and its function is replaced by Indonesian. It is predicted that in the next ten or twenty years the mastery of the G-2 krama level will be increasingly low, from passive mastery to no longer mastering or not understanding. 


\section{References}

[1] G. Leech, Principles of Pragmatics. London: Longman, 1983.

[2] G. Leech, The Pragmatics of Politeness. New York: Oxford University Press, 2014

[3] P. Brown and S. C. Levinson, Politeness: Some Universals in Language Usage. Cambridge: Cambridge University Press, 1978.

[4] R. Scollon and S. W. Scollon, "Intercultural Communication: A Discourse Approach," in TESOL Quarterly (1996) 30(2) 366, Second., Malden: Blackwell Publishers Ltd, 2001, p. 366.

[5] B. Fraser, "Perspectives on politeness," J. Pragmat., vol. 14, no. 2, pp. 219-236, 1990, doi: 10.1016/0378-2166(90)90081-N.

[6] R. J. Watts, Politeness. Cambridge: Cambridge University Press, 2003.

[7] M. Wajdi, "Sistem Kesantunan Masyarakat Tutur Jawa," Linguistika, vol. 20, pp. 1-34, 2013, [Online]. Available: file:///C:/Users/User/Downloads/9706-1-17679-1-10-20140814 (1).pdf.

[8] S. Sukarno, "The Reflection of the Javanese Cultural Concepts in the Politeness of Javanese," K@Ta, vol. 12, no. 1, pp. 59-71, 2010, doi: 10.9744/kata.12.1.59-71.

[9] A. Wijayanto, "The Emergence of the Javanese Sopan and Santun (Politeness) on the Refusal Strategies Used by Javanese Learners of English.," Internet J. Lang. Cult. Soc., vol. 36, no. 36, pp. 34-47, 2013.

[10] [10] B. Indrayanto and K. Yuliastuti, "Fenomena Tingkat Tutur Dalam Bahasa Jawa Akibat Tingkat Sosial Masyarakat," Magistra, vol. 27, no. 91, pp. 37-44, 2015.

[11] H. B. Mardikantoro, "Pergeseran Bahasa Jawa Dalam Ranah Keluarga Pada Masyarakat Multibahasa Di Wilayah Kabupaten Brebes," Humaniora, vol. 19, no. 1, pp. 43-51, 2012, doi: 10.22146/jh.v19i1.890.

[12] M. Wajdi, "Ketidaksetaraan dan Pola Komunikasi Masyarakat Tutur Jawa," Semin. Nas. Bhs. Ibu 4, 2011, [Online]. Available: file:///C:/Users/Windows 10/Downloads/9706-1-17679-1-10-20140814 (1).pdf.

[13] M. Wajdi, "Politeness Systems in Javanese," Denpasar, 2010.

[14] E. al. Poedjosoedarmo, Soepomo, Tingkat Tutur Bahasa Jawa. Yogyakarta: Balai Bahasa Provinsi Daerah Istimewa Yogyakarta, 3013.

[15] A. Ngadiman, "Tingkat Tutur Bahasa Jawa Wujud Kesantunan Manusia Jawa (Dulu dan Sekarang) Agustinus Ngadiman Universitas Katolik Widya Mandala Surabaya,” no. 1981, pp. 1-19, 1974.

[16] E. Jauhari and D. Purnanto, "The Use of Javanese as a Tool of Expression for Solidarity Politeness in the Ethnic Chinese Community in the Javanese Arek Cultural Area," in Advances in Social Science, Education and Humanities Research, volume 338, 2019, vol. 338, no. Prasasti, pp. 140-143, doi: 10.2991/prasasti-19.2019.22. 